\title{
Foraging of Honeybees (Apis mellifera) on Flowers of Yellow Melon (Cucumis melo): Duration of Visits
}

\author{
Márcia F. Ribeiro ${ }^{1}$, Eva M. S. Silva ${ }^{2}$, Lúcia H. P. Kiill ${ }^{1}$, Katia M. M. Siqueira ${ }^{3}$, Mara P. Silva ${ }^{4}$ \\ \& Márcia S. Coelho ${ }^{4}$ \\ ${ }^{1}$ Embrapa Semiárido, Petrolina, PE, Brazil \\ ${ }^{2}$ Universidade do Vale do São Francisco (UNIVASF), Petrolina, PE, Brazil \\ ${ }^{3}$ Universidade do Estado da Bahia (UNEB), Petrolina, PE, Brazil \\ ${ }^{4}$ Petrolina, PE, Brazil \\ Correspondence: Márcia \\ marcia.ribeiro@embrapa.br \\ F. Ribeiro, Embrapa Semiárido, Petrolina, PE, Brazil. E-mail: \\ Received: May 31, 2017 \\ Accepted: July 7, $2017 \quad$ Online Published: August 15, 2017 \\ doi:10.5539/jas.v9n9p7 \\ URL: https://doi.org/10.5539/jas.v9n9p7
}

\begin{abstract}
Studying the pollinators' foraging behaviour is quite important for pollination. Time spent by the pollinator in floral handling is one of the aspects of this behaviour. Honeybees (Apis mellifera) are the main responsible for the pollination of melon (Cucumis melo), but there are few studies on their foraging, mainly in the region of Petrolina, state of Pernambuco, and Juazeiro, state of Bahia, in Brazil. This study aimed to compare bee visitation to hermaphrodite (HF) and male (MF) flowers in a crop area where different number of hives were used. For each floral type, 10 flowers were observed, in each experiment $(0,1,2$ or 3 hives). The duration of bee visits $(\mathrm{n}=10)$ was registered in three times of the day: 8 a.m., 11 a.m., and 4 p.m. In general, HF received significantly longer visits than MF, in all experiments, except when using one hive. In fact, significant correlations were found between the duration of visits and number of hives for HF, but not for MF. This is probably related to the attractiveness of HF and to the availability of floral resources. The studies of duration of pollinator' visits are relevant in agriculture and should be considered when evaluating the efficiency of pollination in melon.
\end{abstract}

Keywords: honeybees, pollination, floral type, foragers' behavior, bee hives

\section{Introduction}

Pollination is usually defined as a mutualistic interaction. However, it involves a conflict between plant and pollinator, since it is based on a balance of costs and benefits for both. Foraging costs for a pollinator can be measured by time spent in floral manipulation and displacement among flowers (Agostini et al., 2014). In this way, studies evaluating the duration of pollinator visits can bring relevant knowledge about the process of pollination.

The main pollinators are bees, including honeybees (Apis mellifera, Hymenoptera: Apidae), which stand out in agricultural pollination. Although wild bees are very relevant for fruit set of crops (Garibaldi et al., 2013), honeybees are still the most used as pollinators, at least in extensive markets of pollination services in USA (Rucker et al., 2012). Concerning the use of honeybees for pollination in Brazil, these bees were mentioned as effective pollinators of 28 crops (Giannini et al, 2015a). In fact, from the 141 evaluated crops in the country, 85 of them had pollinator dependence, and the pollinators presented an expressive contribution $(\sim 30 \%)$ for the total annual agricultural income (Giannini et al., 2015b).

Several studies have shown the importance of honeybees for the pollination of many plants, including Curcubitacea, such as squash (Curcubita pepo; Abu-Hammour \& Wittman, 2010), pumpkin (Curcubita maxima; Nicodemo et al., 2009), water melon (Citrullus lanatus; Araújo et al., 2014; Bomfim et al., 2015), and melon (Cucumis melo; Kill et al., 2011; Siqueira et al., 2011; Sousa et al., 2013; Ribeiro et al., 2015). Melon is a major fruit export in Brazil, and in 2015, the country reached a production of 521,596 tons (IBGE, 2015). The largest melon-producing states are: Rio Grande do Norte (RN); Ceará (CE); Bahia (BA) and Pernambuco (PE). The production of melon in Petrolina (PE) and Juazeiro (BA) is still small compared to the main producing areas: 
Mossoró-Açu (RN) and Jaguaribe (CE). Until recently, in the region of Petrolina and Juazeiro, it was not recorded the practice of introducing hives for pollination services, contrary to what is observed in Mossoró-Açu, where this is already practiced for a long time (Ribeiro et al., 2012). Only recently, it was determined the appropriate number of colonies to be used for pollination of melon in the region. For efficient pollination and a better production of commercial fruit, the recommended number of colonies is 4 hives/ha or 1 hive for each 3,000 plants, since, depending on the spacing, the number of plants per hectare may vary (Ribeiro et al., 2015). Although it is known that honeybees are efficient pollinators of melon (Sousa et al., 2009) and visit both male and hermaphrodite flowers (Siqueira et al., 2011) detailed information on the bees' visitation is scarce. Several aspects are important for studying foraging behaviour, but there are only a few reports regarding the duration of bee vists on flowers (Abou-Shaara, 2014). Considering the above, this study aimed to investigate the duration of visits of honeybees on melon flowers, comparing the floral types, foraging time and bee hives' density.

\section{Method}

\subsection{Sutdy Areas}

In this experiment, we used two areas of $1 \mathrm{ha}$, distanced approximately $9 \mathrm{~km}$ to ensure no influence of one treatment on the others. The first area was located in the Experimental Field of Embrapa Produtos e Mercado and the second in the Experimental Field of Bebedouro, belonging to Embrapa Semiárido, Petrolina (PE). Each area was subdivided into two plots of 0.5 ha with $0.4 \mathrm{~m}$ spacing between plants and $2 \mathrm{~m}$ between rows, totaling 6,250 plants.

\subsection{Material}

The observations were made in experimental areas of yellow melon (Cucumis melo) (hybrid 10/00), with conventional cultivation, plastic sheeting and drip irrigation.

One area was maintained without hives of Africanized honeybees (Apis mellifera), serving as control, and the others received 1, 2 and 3 hives, respectively. The areas received Langstroth hives similar to each other regarding the number of bees and brood. Hives were introduced on the first day of hermaphrodite flowering, and kept until the end of flowering.

\subsection{Sampling Procedures}

\subsubsection{Sample Size}

In the four areas, for each floral type (hermaphrodite flowers, HF, and male flowers, MF), 10 flowers were chosen at random and observed for the behavior of bees during foraging, i.e., the duration of visits. The observations were performed on the $20^{\text {th }}$ flowering day of crops after transplanting, three times a day: at 8 a.m., 11 a.m. and 4 p.m. Thus, 20 flowers were sampled by time, totaling 60 flowers in each of the four areas with different densities of hives $(\mathrm{N}=240$ flowers $)$.

\subsubsection{Measures}

The duration of each bee visit was considered as the permanence time of bees on the flowers from the time of landing until leaving a flower, which was measured with the aid of a digital stopwatch.

\subsubsection{Statistical Analysis}

Data were analyzed using the nonparametric tests of Kruskal-Wallis, Mann-Whitney and Spearman rank correlation (Zar, 2009).

\section{Results}

The analysis of bee visits to two floral types showed a longer duration of visits to HF than to MF (Figure 1). 


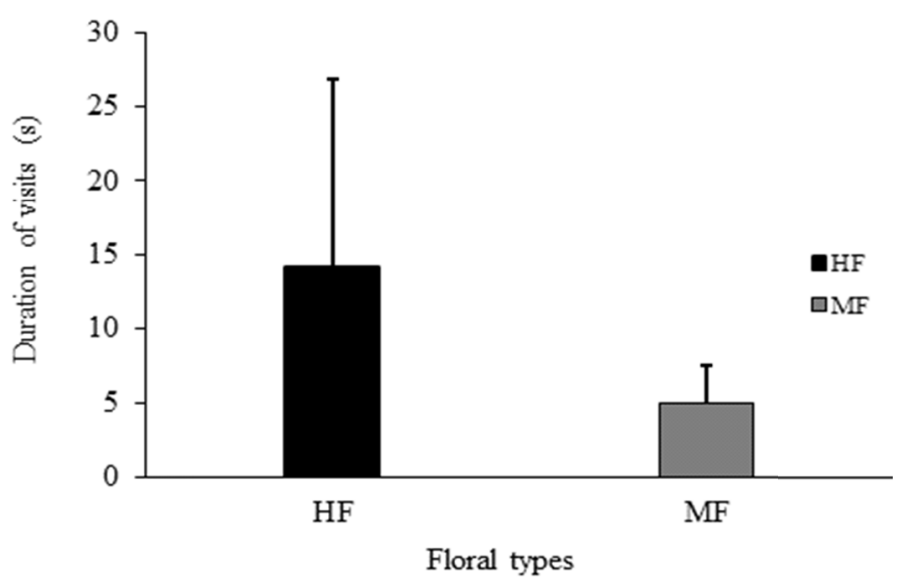

Figure 1. Average duration of visits of honeybees (Apis mellifera) to hermaphrodite (HF) and male (MF) flowers of yellow melon (Cucumis melo)

Note. Bars represent standard deviations.

The average duration of visits of bees to flowers according to floral type (HF and MF) and hive density $(0,1,2$ and 3) confirmed that HF received longer visits than MF. These differences were significant for all areas except for the area with 1 hive (although this value was marginally significant, $\mathrm{P}=0.058$, Table 1 ).

Table 1. Comparison of the duration of visits of honeybees (Apis mellifera) to hermaphrodite (HF) and male (MF) flowers of yellow melon (Cucumis melo), in areas with different densities of hives ( $\mathrm{N}=20$ flowers for each floral type)

\begin{tabular}{lllll}
\hline \multirow{2}{*}{ Floral type } & 0 hive & 1 hive & 2 hives & 3 hives \\
\cline { 2 - 5 } & $\mathrm{M}(\mathrm{SD})$ & $\mathrm{M}(\mathrm{SD})$ & $\mathrm{M}(\mathrm{SD})$ & $\mathrm{M}(\mathrm{SD})$ \\
\hline $\mathrm{HF}$ & $16.00(10.38)^{\mathrm{A}}$ & $9.82(3.09)^{\mathrm{A}}$ & $18.54(14.04)^{\mathrm{A}}$ & $33.11(26.79)^{\mathrm{A}}$ \\
$\mathrm{MF}$ & $4.34(2.17)^{\mathrm{B}}$ & $5.84(3.09)^{\mathrm{A}}$ & $5.13(2.80)^{\mathrm{B}}$ & $5.63(2.60)^{\mathrm{B}}$ \\
\hline
\end{tabular}

Note. Significance for $\mathrm{P}$ values $<0.05$, Mann-Whitney test. Equal letters mean there are no significant differences while different letters indicate significant differences.

The duration of visits of bees depending on floral type and time of day also indicated higher values for HF than for MF (Figure 2). In general, duration of visits was longer in the morning than in the afternoon.

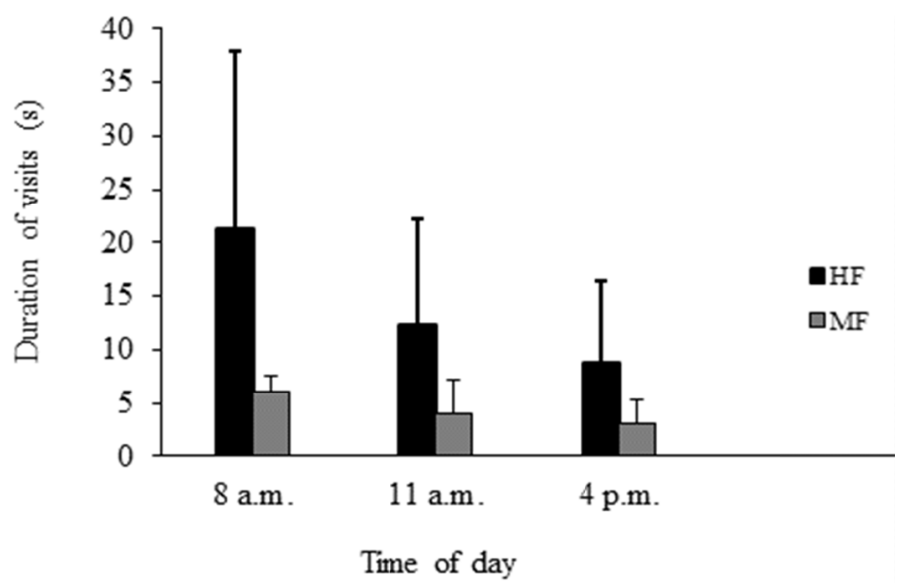

Figure 2. Average duration of visits of honeybees (Apis mellifera) to hermaphrodite (HF) and male (MF) flowers of yellow melon (Cucumis melo), according to different times of the day.

Note. Bars represent standard deviations. 
Differences detected in duration of visits were greater in HF than in MF. In MF, there were no significant differences as a function of the observed times, with values of $\mathrm{P}=0.650, \mathrm{P}=0.219$ and $\mathrm{P}=0.208$ (Kruskal-Wallis, $\mathrm{N}=30$ flowers), respectively, for 8 a.m., 11 a.m. and 4 p.m. On the other hand, the duration was significantly different in HF, with values of $\mathrm{P}=0.001, \mathrm{P}=0.038$ and $\mathrm{P}=0.001$ (Kruskal-Wallis, $\mathrm{N}=30$ flowers), respectively, for 8 a.m., 11 a.m. and 4 p.m. This may indicate that variations in resource availability throughout the day may be greater in HF than in MF.

Comparing the average duration of visits by floral type at each hive density and at each time, it was found that differences were statistically significant, with exception of comparisons for the area with 1 hive (Table 2).

Table 2. Comparison of the duration of visits of honeybees (Apis mellifera) to hermaphrodite (HF) and male (MF) flowers of yellow melon (Cucumis melo), by time of observation, in areas with different densities of hives (Mann-Whitney; $\mathrm{N}=20$ flowers for all comparisons)

\begin{tabular}{llllll}
\hline \multirow{2}{*}{ Time } & Floral type & 0 hive & 1 hive & 2 hives & 3 hives \\
\cline { 3 - 5 } & & MD $(\mathrm{S})$ & MD $(\mathrm{S})$ & MD $(\mathrm{S})$ & MD $(\mathrm{S})$ \\
\hline 8 a.m. & HF & $20.75(13.12)^{\mathrm{A}}$ & $10.83(10.91)^{\mathrm{A}}$ & $24.00(14.84)^{\mathrm{A}}$ & $51.44(32.93)^{\mathrm{A}}$ \\
& MF & $4.62(3.00)^{\mathrm{B}}$ & $5.00(2.22)^{\mathrm{A}}$ & $5.63(3.55)^{\mathrm{B}}$ & $5.64(2.48)^{\mathrm{B}}$ \\
11 a.m. & HF & $14.38(7.73)^{\mathrm{A}}$ & $11.78(8.45)^{\mathrm{A}}$ & $24.18(14.16)^{\mathrm{A}}$ & $26.37(15.86)^{\mathrm{A}}$ \\
& MF & $4.99(1.80)^{\mathrm{B}}$ & $7.71(3.91)^{\mathrm{A}}$ & $5.09(3.01)^{\mathrm{B}}$ & $6.47(3.13)^{\mathrm{B}}$ \\
4 p.m. & HF & $12.88(8.74)^{\mathrm{A}}$ & $6.86(5.26)^{\mathrm{A}}$ & $7.44(3.00)^{\mathrm{A}}$ & $31.53(20.10)^{\mathrm{A}}$ \\
& MF & $3.41(1.21)^{\mathrm{B}}$ & $5.22(2.82)^{\mathrm{A}}$ & $5.29(2.28)^{\mathrm{B}}$ & $4.79(2.06)^{\mathrm{B}}$ \\
\hline
\end{tabular}

Note. Significance for $\mathrm{P}$ values $<0.05$, Mann-Whitney test. Equal letters mean there are no significant differences while different letters indicate significant differences.

The relationship between the duration of visits and the number of hives was significant only for HF (rho $=0.331$, $\mathrm{P}=0.000, \mathrm{~N}=120$ flowers) but not for $\mathrm{MF}$ (rho $=0.156, \mathrm{P}=0.089, \mathrm{~N}=120$ flowers). In this sense, bees effectively spent a longer time in HF in areas with greater number of hives, but the same was not observed for MF.

Bees visited both MF and HF, but stayed longer on HF, especially in the morning and in the areas with the highest number of hives. It is emphasized the importance of long visits of honeybees to HF for efficient pollination and consequent formation of good quality fruit.

\section{Discussion}

Data at Tables 1 and 2 showed that the area with 1 hive was discrepant from the others. All colonies have been standardized as mentioned above, but it is likely that other non-controlled factors have occurred. For example, it is possible that the area with 1 hive has received a different colony, from the genetic point of view, as to foraging behavior of the bees, and thus, both floral types have been similarly visited by bees. Indeed, genetic differences between colonies have been found even in one apiary, concerning productive aspects among others (Matos et al., 2015).

The results found in this work are consistent with the literature, which reports a higher attractiveness of HF, which is attributed to floral morphology and biology, such as diameter of the corolla, nectar chamber height and nectar production (Kiill et al., 2014, 2016). HF is larger than MF, and thus, offer larger landing surface for bees. They are higher and possibly more visible to pollinators. In addition, they have deeper nectar chambers, allowing a greater accumulation of nectar (Kiill et al., 2016). This latter aspect could explain the longer duration of visits of honeybees to flowers. However, this work did not assess floral resources because of the methodology used (only the first 10 bees landing on the flowers were evaluated).

On the other hand, pollen is a resource that takes more time to be obtained, since the grains need to be removed from the anthers of flowers, and then stored in bees' corbiculae. Tschoeke et al. (2015) indeed found that bees spent significantly more time collecting pollen than nectar. Ribeiro et al. (2017), although using a different methodology, also suggested this.

The duration of bee visits was longer in the morning than in the afternoon (Figure 2). Actually, the common foraging behavior of bees is visiting melon flowers at higher density in the morning (Ribeiro et al., 2015). Nevertheless, the observation that the duration is longer in the morning may be related to availability of flower 
resources. In fact, other authors (Sousa et al., 2012; Tshoeke et al., 2015) also reported significant differences in the duration of visits of bees that collected nectar and pollen from melon flowers. Nevertheless, as already mentioned, this aspect was not evaluated herein. Considering the nectar, its production by flowers is continuous throughout the day. HF show a higher frequency of visits (Ribeiro et al., 2015, 2017) and are more attractive (Kill et al., 2014), and replenishment of nectar would be lower in areas with the highest number of hives and, therefore, with the highest number of bees visiting the flowers. The nectar would be reduced more rapidly, and this would lead the bees to stay longer on these flowers to collect the resource. Only more detailed studies on the availability of resources could corroborate this hypothesis. Future studies could include, for example, the investigation of pollen reward and number of bee visits.

Anyway, the longer duration of visits to HF maximizes the contact of the bee with the flower female reproductive structure, which would increase the chances of greater deposition of pollen. Thereby, longer visits to flowers would ensure more efficient pollination.

\section{Conclusions}

Bees visited both MF and HF, but stayed longer on HF, especially in the morning and in the areas with the highest number of hives. It is emphasized the importance of long visits of honeybees to HF for efficient pollination and consequent formation of good quality fruit. Thus, in order to evaluate whether a melon crop area is being adequately pollinated by the native or introduced honeybees, one of the aspects that may be used is the duration of the bees' visits, especially on HF. This could be also a practical manner for the producer to identify the need of increasing the number of honeybee hives in his area, managing the plantation and guaranteeing a high productivity.

\section{Acknowledgements}

We thank CNPq (National Council for Scientific and Technological Development), FAO (Food and Agriculture Organization) and GEF (Global Environment Facility) for financing the study; Mr. Francisco Camilo de Sousa, for his help with the honeybee hives; and Erica M. T. de Alencar, for the translation.

\section{References}

Abou-Shaara, H. F. (2014). The foraging behavior of honey bees, Apis mellifera: A review. Veterinarni Medicina, 59, 1-10. https://doi.org/10.1007/s00244-007-9126-x

Abu-Hammour, K., \& Wittmann, D. (2010). Pollination and Pollinators of Cucurbita pepo (Cucurbitaceae) in the Jordan Valley to Improve Seed Set. Advances in Horticultural Science, 24, 249-256.

Agostini, K., Lopes, A. V., \& Machado, I. C. (2014). Recursos florais. In A. R. Rech, K. Agostini, A. V. Lopes, I. C. Machado (Eds.), Biologia da Polinização (pp. 129-150). Rio de Janeiro, Brasil: Editora Projeto Cultural.

Araújo, D., Siqueira, K., Duarte, P., \& Silva, N. (2014). Comportamento de forrageamento de Apis mellifera na melancieira (Citrullus lanatus) no município de Juazeiro, BA. Revista Verde de Agroecologia e Desenvolvimento Sustentável, 9, 59-67.

Bomfim, I. G. A., Bezerra, A. D. M., Campos, A., Freitas, B. M., \& Aragão, F. A. (2015). Pollination requirements of seeded and seedless mini watermelon varieties cultivated under protected environment. Pesq. Agropec. Bras., 50, 44-53. https://doi.org/10.1590/S0100-204X2015000100005

Garibaldi, L. A., Steffan-Dewenter, I., Winfree, R., Aizen, M. A., Bommarco, R., Cunningham, S. A., \& Klein, C. (2013). Wild Pollinators Enhance Fruit Set of Crops Regardless of Honey Bee Abundance. Science, 339, 1608-1611. https://doi.org/10.1126/science. 1230200

Giannini, T. C., Boff, S., Cordeiro, G. D., Cartolano, J. R., Veiga, A. K., Imperatriz-Fonseca, V. L., \& Saraiva, A. M. (2015a). Crop pollinators in Brazil: A review of reported interactions. Apidologie, 46, 209-223. https://doi.org/10.1007/s13592-014-0316-z

Giannini, T. C., Cordeiro, G. D., Freitas, B. M., Saraiva, A. M., \& Imperatriz-Fonseca, V. L. (2015b). The dependence of crops for pollinators and the economic value of pollination in Brazil. Journal of Economic Entomology, 10, 849-857. https://doi.org/10.1093/jee/tov093

IBGE (Instituto Brasileiro de Geografia e Estatística). (2015). Retrived from http://biblioteca.ibge.gov.br/ visualizacao/periodicos/66/pam_2015_v42_br.pdf

Kiill, L. H. P., Coelho, M. S, Siqueira, K. M. M., \& Costa, N. D. (2011). Avaliação do padrão de visitação de Apis mellifera em três cultivares de meloeiro em Petrolina-PE, Brasil. Revista Brasileira de Fruticultura, 33, 455-460. https://doi.org/10.1590/S0100-29452011000500060 
Kiill, L. H. P., Siqueira, K. M. M., Coelho, M. S., Silva, T. A., Gama, D. R. S., Araújo, D. C. S., \& Pereira Neto, J. (2014). Frequency and foraging behavior of Apis mellifera in two melon hybrids in Juazeiro, state of Bahia, Brazil. Ac. Bras. de Ciências, 4, 2049-2055. https://doi.org/10.1590/0001-3765201420130376

Kiill, L. H. P., Siqueira, K. M. M., Silva, E. M. S., Ribeiro, M. F., \& Feitosa, E. A. (2016). Avaliação de Características Florais de Híbridos de Meloeiro (Cucumis melo L.) na Atratividade de Polinizadores. Revista Brasileira de Fruticultura, 38, 1-12. https://doi.org/10.1590/0100-29452016531

Matos, E. J. A., Ribeiro, D. D., Alencar, A. C. R.., Almeida, J. C., Gouveia, J. J. S., \& Silva, E. M. S. (2015). Caracterização do potencial genético das abelhas Apis mellifera no Vale do São Francisco para comportamento defensivo e produtivo. Paper presented at the X Semana de Ensino, Pesquisa e Extensão da Universidade Federal do Vale do São Francisco, SCIENTEX. Retrived from http://portais.univasf.edu.br/ prppgi/pesquisa/jornada-de-ic

Nicodemo, D., Nogueira-Couto, R. H., Malheiros, E. B., \& De Jong, D. (2009). Honey bee as an effective pollinating agent of pumpkin. Sci. Agric., 66, 476-480. https://doi.org/10.1590/S0103-90162009000400007

Ribeiro, M. F., Silva, E. M. S., \& Lima, C. B. S. (2012). Comparação da utilização de colmeias de abelhas melíferas (Apis mellifera) para a polinização em cultivos de melão (Cucumis melo) nas regiões de Mossoró (RN) e Salitre (BA). Mensagem Doce, 116, 66. Retrived from http://www.apacame.org.br/mensagemdoce/ 116/polinizacao11.htm

Ribeiro, M. F., Silva, E. M. S., Kiill, L. H. P., Siqueira, K. M. M., Coelho, M. S., \& Silva, M. P. (2017). Resource collection by honeybees (Apis mellifera) on yellow melon (Cucumis melo) flowers. Journal of Agricultural Science, 9, 15-20. https://doi.org/10.5539/jas.v9n4p15

Ribeiro, M. F., Silva, E. M. S., Lima Júnior, I. O., \& Kiill, L. H. P. (2015). Honey bees (Apis mellifera) visiting flowers of yellow melon (Cucumis melo) using different number of hives. Ciência Rural, 45, 1768-1773. https://doi.org/10.1590/0103-8478cr20140974

Rucker, R. R., Thurman, W. N., \& Burgett, M. (2012). Honey bee pollination markets and the internalization of reciprocal benefits. Am. J. Agr. Econ., 94, 956-977. https://doi.org/10.1093/ajae/aas031

Siqueira, K. M. M., Kiill, L. H. P., Gama, D. R. S., Araújo, D. C. S., \& Coelho, S. C. (2011). Comparação do padrão de floração e de visitação do meloeiro do tipo amarelo em Juazeiro-BA. Revista Brasileira de Fruticultura, 33, 455-460. https://doi.org/10.1590/S0100-29452011000500063

Sousa, R. M., Aguiar, O. S., Andrade, A. B. A., Medeiros, A. C., \& Maracajá, P. B. (2013). Densidade de colméias com abelhas africanizadas (Apis mellifera L.) para polinização da cultura do melão (Cucumis melo L.) no estado do Ceará, Brasil. Acta Apicola Brasilica, 1, 09-12. https://doi.org/10.18378/aab.v1i1.3586

Sousa, R. M., Aguiar, O. S., Freitas, B. M., Maracajá, P. B., \& Andrade, C. B. M. (2012). Grazing behavior of Africanized honeybees (Apis mellifera L.) in flowers of yellow melon (Cucumis melo L.). Revista Verde, 7 , 233-238.

Sousa, R. M., Aguiar, O. S., Freitas, B. M., Silveira Neto, A. A., \& Pereira, T. F. C. (2009). Requerimentos de polinização do meloeiro (Cucumis melo) no município de Acaraú-CE-Brasil. Revista Caatinga, 22(1), 238-242.

Tschoeke, P. H., Oliveira, E. E., Dalcin, S. M., Silveira-Tschoeke, M. C. A. C., \& Santos, G. R. (2015). Diversity and flower-visiting rates of bee species as potential pollinators of melon (Cucumis melo L.) in the Brazilian Cerrado. Scientia Horticulturae, 81, 207-216. https://doi.org/10.1016/j.scienta.2015.02.027

Zar, J. H. (2010). Biostatistical Analysis (3rd ed.). New Jersey, Prentice Hall.

\section{Copyrights}

Copyright for this article is retained by the author(s), with first publication rights granted to the journal.

This is an open-access article distributed under the terms and conditions of the Creative Commons Attribution license (http://creativecommons.org/licenses/by/4.0/). 